\title{
CLIL bilingual Research Results at Spanish University Level Including Academic Content Work
}

\author{
Elaine Hewitt \\ University of Granada, Spain
}

\begin{abstract}
This original empirical study looked into the results of one type of cross-disciplinary education begun in recent years in Spain. The latter country has a policy of bilingual or CLIL Content and Language Integrated Learning throughout its secondary schools (for example, Plan for Encouragement of Plural-lingualism: A linguistic policy for Andalusia: Andalusia Education Council, 2005). However, little research has been carried out on the efficacy of this system at secondary school, and much less on a follow up of these students at university level. The present study goes a long way into rectifying this as this research describes part of the results at university level found by a national $r+d$ project (research and development) devised by, and awarded to, its current director - the present author. The research project took data on the tracking and evaluation of students coming into higher education from bilingual secondary schools at the University of Granada. The participants in the initial phase of this research project were 31 Spanish-speaking university students of elective bilinguals. Within a pre-experimental design, over one academic year they completed one background questionnaire and four psychometric tests. Results are reported with Pearson correlations, and where necessary Kendall's Tau Non-Parametric analysis for extra high confidence in the investigation. These revealed the areas where the participants' independent subject variables were important. Coyle, Hood and Marsh (2010) came to the conclusion that research into bilingual CLIL Content and Language Integrated Learning, should also take data on the results of the academic content work as well as on linguistic outcomes in CLIL settings. Thus, I have collected information on both types in my empirical study reported in the second half of this article.
\end{abstract}

\section{Introduction}

The resulting bilingual or CLIL (Content and Language Integrated Learning) education currently carried out in some Spanish secondary education centers first began with the initial norms that had made their way over from northern Europe. In Andalusia, in the south of Spain, its bilingual education has also been developed in this way - the same as in other Spanish regions. Locally, this type of education is organized according to the document of the Andalusia Education Council [2] also called the "Plan for Encouragement of Plurallingualism: A linguistic policy for Andalusia". The first European programs of linguistic educational cooperation were elaborated in 1957 in Strasbourg by the Department for Linguistic Policies. Its history continues to unfold with the European Commission's "White Book on Education and Training" for the year 1995 and additionally, the several resolutions of the Council of Europe. These verified the necessity of taking into account European cultures and languages. All of this finally found its way into the famous work called the European Common Framework of Reference for Languages: Learning, teaching, evaluation (ECFRL) of the European Commission for the year 2000. This document has had much influence all over Europe and it was translated into Spanish in the year 2002. In order to specifically improve the knowledge of English as a foreign language (FL), the Spanish Ministry of Education together with the British Council [4] began a smaller bilingual education project around the end of the decade of the 1990s. Little by little, this has reached more and more Spanish state secondary school centers.

Andalusia began to elaborate its regulations for the teaching of foreign languages with the Royal Decree number 942 of the 9th of May, 1986. The regulations began with the second cycle of infant education. On the 2nd of March, 1998 bilingual departments were established with the signing of an Elaboration Protocol between the Education and Science Council of the Board of Andalusia and the Ministry of Foreign Matters of the French Republic. This saw the installation of bilingual services in schools within the region of Andalusia.

Later the German and English languages were incorporated until finally this resulted in the aforementioned: Plan for Encouragement of Plurallingualism. It was published by the Education Board on 22 of March, 2005 in the BOJA (the Board of Andalusia's Official Bulletin). As can be 
seen, Andalusia was the final region to do this and subsequent to other countries and communities in Europe.

As Martín [15] recounts: "In the present year of 2007-08, more than 1,000 state centers have been included within this bilingual educational program, but this will go on increasing year after year. Andalusia is a pioneer in this material and will apply the most extended model, that of bilingual departments. It is considered a model that will gradually offer reconciliation between the FL (foreign language) and the student, which will increase with time. As of the $5^{\text {th }}$ academic grade of primary the academic load of the second language will be augmented and in secondary, in addition to the corresponding hours devoted to the foreign language, two other courses minimally will be imparted in the foreign language”. It is here where it may be clarified that the latter model specified in the quote above is one better known as CLIL (Content and Language Integrated Learning) rather than bilingual education proper.

The goals of our $\mathrm{r}+\mathrm{d}$ project (research and development) have several facets. Above all, the main purpose of this project is one of establishing what seems be in Spain the first control and followup specifically in the university, of students originating from the system of bilingual CLIL secondary education. Because nothing similar exists to date and it is obvious that something had to be set up immediately, the Spanish Education Ministry has been officially financially backing our proposal and research project for two years now.

The specific study that we aim to accomplish with this project is empirical in nature and its research includes new data collected within the classroom according to the strict norms, ethical and empirical requirements of projects of this type. Not only will it gather the results of other investigators from their volumes of work in libraries, for example, but it will also be in touch with the fundamental source of this data - our university classrooms and lecture halls. This should be carried out using the referents available in the Common European Framework of Reference for Languages (European Commission, [5]), and according to the new curricular designs of university, primary and secondary education in Spain.

Another of the principal purposes of the project is going to be the said evaluation of the students that have originated from the system of bilingual secondary CLIL education once they and their existence in the university are located. The most important evaluation will be, as is logical, of their level of the studied foreign language, English in this case. However, we will also be evaluating other factors such as psycholinguistic and/or cognitive aspects and moreover, this particular article reports on the results of the newer aspect of academic content work.

An additional purpose is found in the next step and this will be an analysis of a comparative type of all the students in the study. Because of this, on the one hand the data gathered off the students originating from the bilingual CLIL system will be contrasted with those who do not originate from this system. It would be interesting to set up more research enquiries into such an expensive system. Within this article, the first results are described.

We begin our research in a number universities - few at the beginning - those where the members of this project are affiliated. This will be carried out in a gradual manner. In this way, we can demonstrate that not only the present purposes are possible to achieve but also any improvements to the research design.

Research into bilingual education in other countries has found that the curriculum in the school itself plays an essential role in establishing if being bilingual has more positive than negative outcomes. In general, advantages are associated with immersion programs while disadvantages are associated with submersion programs. Immersion refers to "immersion programs", a style of bilingual education where children speaking only one language attend a school where the classroom language is a second language. For example, Anglo-speaking children attending schools in Canada where teaching is imparted French. Submersion refers to "submersion programs"; another means of bilingual education in which the main language used is that of only a proportion of the pupils. This occurs in various countries where immigrant children enter schools where the teaching is given in the language of the host country.

Cummins and Swain [7] state that pupils were the same or better than other similar English groups in reference to English and study skills learning under a French immersion program. No differences were found in science or math with the comparison groups. On some of the instruments, these pupils in the immersion program achieved results in French that were similar to natives of this language.

The outcomes of a long-standing EFI appraisal (Early French Immersion) of the CBE (Carleton Board of Education) and the OBE (Ottawa Board of Education) and others (Andrew, Lapkin and Swain [3]; Genesee [11) put forward two principle findings. The first was that it is possible to build up a substantial level of bilingualism, through programs with a pertinent FSL design (French as a Second Language). This may be done without preoccupation about any long-standing negative consequences for academic, cognitive or first language skills. Indeed, positive effects have been seen on first language skills. The second outcome 
was that it the positive results could not be fully recognized until the immersion program was far along in its progress, which highlights the importance of long-standing evaluation. It was demonstrated that pupils with English as a second language need between five and seven years in order to get up to the average academic and cognitive English levels of the rest of their L1 fellow English pupils.

We may surmise from this that interpersonal communication skills are not the same as the cognitive and academic levels. This is comparable to the progression in pre-school children when they are acquiring their first language (Donaldson, [8]). These interpersonal communication skills are distinct from academic ones.

Hamer and Blanc [12], affirm that sufficient exposure to the language in school is vital for the subsequent development of academic skills. Nevertheless, maybe even more vital is that pupils learn the academic input they have been exposed to. In minority-language students, this input is unequivocally linked to conceptual aspects that build up because of exposure to the first language.

This does not indicate that exposure to a language is unimportant - just that the cognitiveacademic skills in the first language of minority mother-tongue pupils are as imperative as exposure to the second language for the development of these same skills in the second language.

The same authors indicate that behind poor academic performance lie social-structural, socialcultural, and tricky social-psychological factors that are more central than the factor of bilingualism. Nonetheless, these factors fluctuate between communities, and so a single solution is not possible but each instance must be considered independently.

Even so, these researchers have detected some facets of programs that have proven their success. These are that all of these programs should teach the first language before or simultaneously with the second language. In this way, the pupil is motivated to learn the first language or has the linguistic concepts stimulated through the first language, and so gains a better level of the second language. Thus, bilingual education is a necessary -but not the only factor - for a minority language child. The allegiance to his community and active use of the first language at home are just as vital.

In the case of low socio-economic homes or in those where the language in use is discredited by its own members and others, it seems beneficial to start education in the child's first language. Conversely, initial teaching in the second language gives better outcomes where the language at home is the majority language, is esteemed in the community and it inspires the capacity for reading and writing at home (Swain and Bruck [23]; Tucker [24]).

In conclusion, important facets include the need for evaluation that is long-term. To appreciate the cognitive and academic results of bilingual education a period of 5 to 7 years is necessary. Socio-cultural, socio-structural and socialpsychological factors have much transcendence in the origin of poor academic performance as do the significance of the family context and of the home.

Immersion bilingual education is similar to the CLIL - Content and Language Integrated Learning that concerns us in the original research I have carried out in the second half of this paper. However, we may also take into account that partial or late immersion is still more similar and all that said above may be applicable largely to CLIL. Coyle, Hood and Marsh [6] state that partial immersion programs have not been found to be as successful as total immersion programs. Late immersion programs were found to be successful if some teaching in the foreign language had been carried out a few years before immersion began. The same authors put the latter down to the necessity of language-competence threshold levels being arrived at first and before beginning immersion. At the moment, in Andalusia, CLIL bilingual programs mean late-partial immersion.

Coyle, Hood and Marsh [6] concluded that research into bilingual CLIL Content and Language Integrated Learning, needed also to collect data on the results of academic content work as well as on linguistic outcomes in CLIL settings. Airey [1] researched a CLIL educational context for its university science content-based outcomes. He encountered assorted results with no clear conclusions except that students' higher or lower achievement was reliant on various aspects associated with content as well as language. This research also found that some of these Swedish undergraduate students still had difficulty in speaking in English about science. I have borne in mind the advice about the need to take data on the content or factual material as well as the language. Thus, I have collected information about both types in my empirical study reported below.

\section{The empirical study}

\subsection{Objectives of the project}

The objectives were to control, investigate and to measure for the first time, through the use of scientific instruments, the relationship that the level of CLIL bilingualism has with the learning of the foreign language, the development of the linguistic skills, the content or factual material and other variables of a demographic type in university students in Spain. Specifically, it is to be carried 
out with university students on courses related to English as a foreign language.

The present research proposed to go into the university and to obtain in an empirical way data directly from the students. Obviously, in this type of research one does not know if there are going to be students originating from the secondary bilingual system (CLIL) or not, in the specific students to be sampled. Nevertheless, it is the type of research that may come up with the most original and novel data, than, say research only done in the library.

\subsection{Research rationale}

In the present project to date, we have been able to investigate over 200 university students all over Spain, and over 1,000 questionnaires, tests and surveys have been processed that the said students have completed. In total, we have obtained more than 47,000 items of data. In most instances, some details are being still analyzed since with this large volume of research a fair amount of time is needed.

Subsequently, all the answers and variables of each questionnaire and of each student were scored, giving a numerical value to each one and to each student and thereinafter the figures were put into the statistical package SPSS [22] to be analyzed.

The students were adequately informed and their permission sought, furthermore with a model for the said letters of permission already piloted to request such authorization. In addition to this, two obligatory ethical agreements and confidentiality letters had been signed with the Ministry of Education, as well as with the Ethics Committee at Granada University. Each member of the project considers the data of the students as sensitive and which must be protected and looked after with absolute seriousness.

\subsection{Operational definitions}

Since, at university level and in areas of Spain like Andalusia that do not have a second national language (no natural bilingualism) there has been very little research done or written so far on the topic of bilingual CLIL and plurilingual education, this project will provide a contribution to that area. It goes without saying that there is great quantity already published in English, but mostly referring to the Canadian context. The aforementioned context is different to ours, as much as to Europe, to Spain and to Andalusia.

For orientation with the present operational definition, we may emphasize that for the concept of bilingual or CLIL education in Spain the latter is mostly of the AICLE type in Spanish called: Aprendizaje Integrado de Contenidos y Lengua or in their original initials in English: CLIL (Content and Language Integrated Learning).

Now, at this current point of argument it has been convenient to clarify the above operational definition of bilingual education as used here due to the confusion raised by the Spanish authorities in naming the said secondary centers in Spain as bilingual. In fact, this is not bilingualism really, as within this latter system the secondary school students only study the content of one or two subjects in the foreign language, for example, environmental studies or math through English. In reality, these centers impart the CLIL system which is a cross disciplinary type of education through the medium of the foreign language.

Bilingual education properly defined is obviously, that of for example, French and English in parts of Canada. That is to say, an L2 is considered the second language and the one where according to the Longman Dictionary of Applied Linguistics (Richards, Platt and Weber [21], p.108), the L2 is not the native language of a country but one that is however, used as a medium of communication. For instance, the second language is present in the organs of education and government and in a parallel way to that country's other native languages. Ellis [9] defines the second language as a form of communication also important outside of the classroom.

Obviously, we not are comparing the CLIL of our secondary schools in Andalusia to the type of bilingualism that is found in India or Canada. The former is concerned with the foreign language. The definition of foreign language is given by Richards et al., [21], as one which is not native to a given country but one that is studied and used in communication with other foreign people each in their own countries or used so as to be able to read material printed in that foreign language. A foreign language does not tend be as nearly as important for the students outside of the classroom as a second language does (Ellis [9]). The foreign language is one that is studied in a more conscious way and usually in an academic and formal context.

\subsection{Steps}

2.4.1. Participants. In this article, I am going to describe for the moment the participants comprising the first batch of students sampled, those from the University of Granada in the south of Spain.

The students sampled at this first university were 40 in all of Spanish speaking elective bilinguals, finally resulting in a total of 31 students perfect for the purposes of analysis here. All were studying the Bachelor's degree in English Studies at university and specifically, and were registered 
on the obligatory annual course of Applied Linguistics for Language Teaching of the second academic year. There were 5 males and 26 females with ages between 19 years old and 40 years and 7 months old. There was only one student with the latter age and the average age was of 19 years and 1 month. $6 \%$ of these students originated from the bilingual or CLIL (Integrated Content Learning and Language) Spanish secondary school system. Through the foreign language (English) at secondary school, the first student had studied mathematics, biology and religion while the other student had studied the course of English language. The first student was of Spanish nationality with a German family background and the second was of Moroccan nationality.

2.4.2. Tests used. There were a total of 6 types of instruments used. The suitability of each test for this field had already been proven in previous pilot studies by the current author, also director of this project. The instruments were:

1) Test of aptitude for languages (PLAB 2003),

2) Questionnaire on language motivation (AMTB, Gardner [10]),

3) Questionnaire or Foreign language classroom anxiety scale (FLCAS, Horwitz, Horwitz, and Cope [14]),

4) The QPT, a test of level of English as foreign language (Oxford University Press and University of Cambridge Local Examinations Syndicate, [19]),

5) The DPFBP questionnaire of personal data that collected information on the demographic variables of the students and on their education in the bilingual or CLIL secondary schools in Spain (Hewitt [13]). This included the data that describes the participants in the above paragraph.

6) End of year final grade in content work, which in this case was the obligatory course called Applied Linguistics for Language Teaching on the degree of English Studies.

\section{Results}

In this section, we describe the results in the same order as the instruments listed above.

\subsection{Results for the PLAB test of aptitude for languages}

A global mark on the PLAB test of aptitude ranging from 117 to 70 points indicates a student with a high aptitude and possibility of success with languages in the academic system. Between 69 and 50 points indicates average success. Between 49 and 1 point means scarce success probable. The results for this sample can be contemplated in Table 1:
Table 1. Points obtained on the PLAB test of language aptitude and their meanings

\begin{tabular}{|l|l|}
\hline $\begin{array}{l}\text { Meaning and total } \\
\text { points obtained in the } \\
\text { PLAB }\end{array}$ & Number of students \\
\hline $\begin{array}{l}\text { 117-70 points - student } \\
\text { with a high aptitude for } \\
\text { languages }\end{array}$ & 27 students \\
\hline $\begin{array}{l}\text { 69-50 points - will have } \\
\text { average success }\end{array}$ & 4 students \\
\hline $\begin{array}{l}\text { 49-1 point - scarce } \\
\text { success probable }\end{array}$ & 1 student \\
\hline
\end{tabular}

Out of the total of 31 students in this sample, positively most of the students got between 117 and 70 points - that is to say - a high aptitude for languages.

Four students got between 69 and 50 points, implying average aptitude. There was one student in the category of scarce probable success with languages of between 49 and 1 point (scarce aptitude)

The average mark was of 79.2 - which falls within the category of high aptitude for languages. The maximum score was 93 points and the minimum in this category was 71 points.

The 2 students originating from bilingual CLIL secondary schools got 86 and 73 points respectively on the PLAB - both obtaining a mark of high aptitude for languages. One of these students got more than the average score for the class and in the case of the other student - less than the average figure, but still relatively high.

We will refer now to the specific sub-sections of the PLAB test: The first part of the PLAB measures the total average marks obtained whilst in secondary school and over several school subjects, the total possible is 16 points. Most of the students informed us of high marks for this category, the lowest being 7 points.

For part 2: Interest in foreign language learning, the total possible was 8 points and everybody obtained either 8 or 6 points. This demonstrates that the interest and motivation of the whole sample is high. The bilingual CLIL students also obtained 6 and 8 points respectively.

In part 3, Vocabulary - knowledge of words in English - the total possible score was of 24 points. The lowest mark was of 5 points and the highest was of 19 points. The bilingual CLIL students obtained 14 and 5 points.

For part 4: Language Analysis - which meant the ability to reason with logic in terms of the foreign language - the maximum possible was 15 points and four students got the maximum. The bilingual CLIL students got 11 and 8 points. 
Part 5: was Sound Discrimination - the ability for learning new phonetic distinctions and to recognize them in different contexts. The maximum score possible was of 30 points. The maximum obtained was of 27 points and the minimum 10. The CLIL bilingual students obtained 20 and 21 points, which were good marks.

For part 6: Sound Association of Symbols, is the sounds' association with their written symbols. The maximum possible score was 24 points. The class in general obtained a maximum of 23 and a minimum of 9 points, which is reasonably good. The bilingual CLIL students got 21 and 21 points, also very good.

\subsection{Results for the FLCAS scale of anxiety in the classroom results}

The maximum possible score on this scale is 165 points and one that would demonstrate a very anxious student. Between 100-88 points would be a student who is neither very anxious, nor very relaxed. Between 87 and 33 points would show the score for quite a relaxed student.

In Table 2 the scores for anxiety in the English classroom can be seen.

Table 2. Points obtained on the FLCAS anxiety scale, number of students and their meanings

\begin{tabular}{|c|c|}
\hline $\begin{array}{l}\text { Meanings on the } \\
\text { FLCAS and points } \\
\text { obtained }\end{array}$ & Number of students \\
\hline $\begin{array}{l}165 \text { to } 101 \text { points - a } \\
\text { very anxious student }\end{array}$ & 10 students \\
\hline $\begin{array}{lcr}\text { 100-88 } & \text { points - } & \text { normal } \\
\text { average } & \text { mark of a } \\
\text { student } & \text { neither } & \text { very } \\
\text { anxious, } & \text { nor } & \text { very } \\
\text { relaxed } & & \end{array}$ & 10 students \\
\hline $\begin{array}{l}87-33 \text { points - quite a } \\
\text { relaxed student }\end{array}$ & 11 students \\
\hline
\end{tabular}

There were 10 very anxious students, another 10 students who were neither very anxious, nor very relaxed and 11 quite relaxed students. The average figure was of 93.38 - meaning a student who is neither very anxious, nor very relaxed. The two students originating from the bilingual CLIL secondary schools obtained on the FLCAS: 99 points (normal, neither very anxious, nor very relaxed) and 61 points (quite relaxed).

\subsection{Results for the QPT test of level of English results}

To reveal the level of English we may explain that the scoring system is as follows and based on the criteria of the European Commission: Elementary (18-29 points), Lower Intermediate (30-39 points), Upper Intermediate (40-47 points), and Advanced (48-54 points), and Very Advanced (55-60 points). The outcomes can be envisaged in Table 3 grouped into each level.

Table 3. QPT test of level of English: number of students, their English level and meanings

\begin{tabular}{|l|l|l|}
\hline $\begin{array}{l}\text { European Council and } \\
\text { ALTE categories }\end{array}$ & $\begin{array}{l}\text { Possible score } \\
\text { on the two } \\
\text { parts of the } \\
\text { QPT test }\end{array}$ & $\begin{array}{l}\text { Number of } \\
\text { students }\end{array}$ \\
\hline $\begin{array}{l}\text { 0. Beginner } \\
\text { (Breakthrough) A1 }\end{array}$ & $0-17$ points & ---- \\
\hline $\begin{array}{l}\text { 1. Elementary } \\
\text { (Waystage) A2 }\end{array}$ & $18-29$ points & 10 students \\
\hline $\begin{array}{l}\text { 2. Lower Intermediate } \\
\text { (Threshold) B1 }\end{array}$ & $30-39$ points & 12 students \\
\hline $\begin{array}{l}\text { 3. Upper Intermediate } \\
\text { (Independent) B2 }\end{array}$ & $40-47$ points & 8 students \\
\hline $\begin{array}{l}\text { 4. Advanced } \\
\text { (Competent) C1 }\end{array}$ & $48-54$ points & 1 student \\
\hline $\begin{array}{l}\text { 5. Very Advanced } \\
\text { Very Competent) C2 }\end{array}$ & $55-60$ points & ----- \\
\hline
\end{tabular}

One student obtained Advanced level (C1). Eight students obtained an Upper Intermediate level, 12 students got Lower Intermediate level, and 10 students the Elementary level. No student got Beginner level and no student got the category of Very Advanced (level C2 of the European Common Framework).

The average figure was 33.96 (lower intermediate level). The two students originating from bilingual CLIL secondary schools obtained on the QPT English level test as follows: 44 points (Upper Intermediate) and 37 points (Lower Intermediate). If they are compared with the other students in the class these two students got amongst the highest marks in this group and they obtained higher than the average figure.

A t-test related samples analysis was performed with the QPT level of English test and the bilingual CLIL students. The bilingual CLIL students' 
English level marks were significantly better than the rest of the class: $t=25.206, d f=30$, significant at level $p \leq=.0001$.

\subsection{Results for the AMTB test battery of attitude and motivation to English results}

The maximum mark possible on the attitude and motivation questionnaire to the English language on the AMTB (Gardner [10]) - is that of 708 points and the minimum 0 points. The results of this study and the sample with AMTB may be envisaged in Table 4:

Table 4. Points obtained in the AMTB on attitude and motivation with English and their meaning

\begin{tabular}{|l|l|}
\hline AMTB points obtained & Number of students \\
\hline $\begin{array}{l}\text { 708-408 points - Very } \\
\text { motivated }\end{array}$ & (All) 31 students \\
\hline $407-207$ points & ---- \\
\hline $206-100$ & ---- \\
\hline $100-0$ points & ---- \\
\hline
\end{tabular}

All these students obtained high marks denoting a very positive attitude and motivation toward English as foreign language. Scores ranged from 631 to 432 points, with an average figure of 534.54.

The two students originating from bilingual CLIL secondary schools obtained the following on the AMTB: 539 and 601 points respectively, which are higher than the average figure for this group for motivation.

\subsection{Results for the content work or factual material}

All of the students in this sample were on a university degree in English Studies and consequently were in a class studying an obligatory course of Applied Linguistics for Language Teaching. Specifically, the main part of the mark for the end of year grade in content work for the obligatory course Applied Linguistics for Language Teaching was comprised of an end of year exam. The exam was made up of various essays based on the program of this course, which included such questions as: 'Describe the theory and research behind, and practical activities for, teaching the vocabulary of English as a foreign language'. Alternatively, about Teaching Speaking: 'Write about the factors involved, interactions and classroom activities for teaching this skill'.

These non-native students had to write these essays in the English language, which was their foreign language. This aspect was compulsory because the course was part of the said degree in English Studies. However, necessarily it was the content on Applied Linguistics for Language Teaching, not the level of English that was to be graded. Nevertheless, the students were knowledgeable in both. The end of year grades in the content work were compared with the students' marks on numerous other variables, in particular correlation analyses were carried out.

The results of the grades of this content work when compared to other facets of this study were as follows.

\subsection{General results for the academic content work}

3.6.1. The obligatory course of 'Applied Linguistics for Language Teaching'. The average mark for factual material of the content subject Applied Linguistics for Language Teaching was 6.68 out of 10 . The maximum mark was 10 out of 10 , the minimum was 1.3 and overall the standard deviation was of 2.53 marks. The pass mark was 5 out of 10 and the bilingual CLIL students gained 9 out of 10, and 7 out of 10 . These were higher than the average mark of this class for the factual material.

A t-test related samples analysis was calculated to find if the bilingual CLIL students' academic content marks were significantly different and better than the rest of the class. It was found that this was indeed the case and there was a statistically significant result: $t=18.036, d f=30$, significant at level $p \leq=.0001$.

The next step was to find out in general and with the whole class, what exactly the content matter grade did have a relationship to. It was found that no other variable except one correlated significantly with any other facet. The only other variable that correlated in relation to the content matter in order to give us a clue to its strongest characteristic was that of Language Analysis. This is sub-section 4 of the PLAB Test for language aptitude - the ability to reason with logic in terms of the foreign language: Pearson's $r=.523$, significant at level $p \leq .003$. This could possibly indicate that this ability is what, to some extent, enables the essay writing of the students in this sample - at least as regards the area of content work. In addition, it indicates they are using this ability for reasoning with logic to complete the task of writing their factual material answers.

There was no statistically significant correlation between the content matter grade and level of English on the QPT level test. Nor was there any between the content matter grade and parts 1 or 2 of the PLAB Test of marks obtained in secondary school or interest in foreign language learning - the 
interest and motivation for learning English respectively. This was probably because the content matter grade was based on academic characteristics and written reasoning - not on the students' foreign language ability - even though the essays had to be written in the foreign language. We may also speculate that other aspects such as motivation to obtain a university degree or other extrinsic motivations may be related to higher grades in the obligatory course content. It would be interesting to take data on the latter - as well as more data related to the obligatory content course in general.

3.6.2. Grade point average. Under this area of content learning, we may also include the Grade Point Average, which the students gave about their general progress on the current Bachelor's degree in English Studies.

At this university the total Grade Point Average is also calculated out of ten, thus the highest mark for this sample was 10 , and the lowest 5 . The average mark of this sample was 7.12, with a standard deviation of 1.32. The CLIL bilingual students' Grade Point Average was 8 and 6.3, the first being higher and the second lower than the average grade obtained by this sample.

With the sample as a whole, the variable for Grade Point Average correlated statistically and significantly with the following two variables:

Grade for the course Applied Linguistics for Language Teaching: Pearson's $r=.564$, significant at level $p \leq .001$.

PLAB Test of aptitude for languages; Pearson's $r=.592$, significant at level $p \leq .001$. However, the University Entrance Exam grade was not significantly related, nor was being a CLIL bilingual student significant to the Grade Point Average.

To sum up, the fact that the grade on this obligatory course content was also statistically and significantly correlated to the students' selfreported grade point average for the whole degree, adds reliability to the teacher grades given for this obligatory course. This is because it translates as those students who were achieving the highest marks on the degree had also been graded as achieving the highest marks on the obligatory course.

This finding that there was a statistically significant correlation between Grade Point Average on the whole degree with the Grade for the course of Applied Linguistics for Language Teaching is encouraging. This means therefore that the course exam is measuring the same academic aspect as the degree as a whole and so although the students' exams have to be written in English this grade is not merely measuring the students' level of this their foreign language but indeed and primarily the course content or factual material.

There was, however, no significant correlation between the grade on the University Entrance Exam and the course content grade. This could be due to the fact that the University Entrance Exam in Andalusia examines various fields and not just the area covered by this degree. Being a CLIL bilingual student was not significantly correlated to the Degree's grade point average either.

Nevertheless, a t-test did show a significant difference between the bilingual CLIL students and the rest of the sample on this variable of grade point average: $t=24.22, d f=28$, significant at level $p \leq=.0001$. The average mark was 7.12 out of 10 - the bilingual CLIL students got 8 and 6.3, out of 10 and were found to have a significantly better Grade Point Average than the rest of the class.

\section{Discussion and Conclusions}

We are still analyzing the more than 47,000 items of data and so far have made good headway with the task - though logically with such a large volume of data, much work still remains to be done. Constructively, what was anticipated for this stage in the proceedings has been carried out so far.

Concerning any conclusions that may be derived from the results described above, we will first sum up the class as a whole then move on to look at the CLIL bilingual students specifically.

With the QPT test the level of the English in the sample, one student obtained an Advanced level. Eight students obtained an Upper Intermediate level, twelve students got Lower Intermediate level, and ten students the Elementary level. The average level was lower intermediate.

On the PLAB test of aptitude in languages the majority of the class obtained a high mark. In the individual sections of this test, the class as a whole obtained their highest mark with part four: Language Analysis - the ability to reason with logic in terms of the foreign language. In part six, again good marks were obtained in Sound Association of symbols, and their sounds' association with their written symbols.

With the FLCAS anxiety in the classroom scale, the average figure shows an average student who is neither very anxious, nor very relaxed. For the AMTB test of attitude and motivation to and for the English language (Gardner [10]) all the students obtained a very high mark showing a very positive attitude and motivation toward English as foreign language. Furthermore, for the class as a whole there were significant correlations between this variable and the mark on the English level test.

As Coyle, Hood and Marsh [6] pointed out, research into bilingual CLIL Content and Language Integrated Learning, should also compile figures on 
content work as well as on language levels in CLIL settings and I have done this with the present sample. Results of the content work or factual material for this sample specifically made up of students on a course of Applied Linguistics for Language Teaching off an English Studies degree, was revealing. It is amongst some of the first data taken on this aspect that has been reported to date.

The content matter grade for the sample in general had a positive relationship to the variable of the ability to reason with logic in terms of the foreign language. The latter was sub-section 4 of the PLAB Test for language aptitude and this variable is called Language Analysis. This probably indicates that this is one of the factors that helps this sample as a whole to complete the task of writing their factual material essays.

We have speculated that it would be interesting to take data on external motivation inherent in obtaining a university degree or other extrinsic motivation - the latter in order to find out more about the factors influencing grades of the obligatory content course in general.

Under this area of content learning, the Grade Point Average was also included. The variable for Grade Point Average correlated statistically and significantly with the Grade for the course Applied Linguistics for Language Teaching and the variable of the PLAB Test of aptitude for languages. This means that this gave reliability to the grades of this obligatory course because those students obtaining the highest marks on the obligatory course had also obtained the highest marks on the degree. The course exam therefore, is correctly measuring the same academic aspect as the degree as a whole the factual material - and even though the students' exams have to be composed in English this grade is not just measuring the students' level of their foreign language.

Now to specifically discuss and draw some conclusions on the students originating from the bilingual or CLIL secondary school system. For level of English, these two bilingual or CLIL students obtained Upper Intermediate and Lower Intermediate on the QPT English level test. If contrasted with the other students in the class, these two students obtained amongst the highest marks in the group.

A t-test related samples analysis was carried out with the QPT level of English test and the bilingual CLIL students. The bilingual CLIL students' English level marks were significantly better than the rest of the class.

The same students managed to get a high aptitude global score for languages on the PLAB. Moreover, they obtained good marks, above all, on part 5: Sound Discrimination - the ability for learning new phonetic distinctions and to recognize them in different contexts. Also on part 6: Sound -
The Association of the symbols - that is sounds' association with their written symbols.

On the FLCAS scale of classroom anxiety these two students were respectively found to be neither very anxious, nor very relaxed and quite relaxed. On the AMTB questionnaire of attitude and motivation to English these two students got high marks, both of which were higher than the average figure for motivation of the class.

The general results for the academic content work of Applied Linguistics for Language Teaching showed that the plain mark of bilingual CLIL students' was higher than the average mark for progress with the factual material. Additionally, the t-test found that the bilingual CLIL students' academic content marks were significantly better than the rest of the class.

The first CLIL bilingual student's Grade Point Average was higher and the second student's was lower than the average grade obtained by this sample as a whole. However, Grade Point Average was not significantly related to the University Entrance Exam grade, nor to being a CLIL bilingual student.

In conclusion, the bilingual CLIL students gained higher than the average mark for their course on Academic Content Work. The CLIL bilingual students Grade Point Average was: 8 and 6.3 , the first being higher and the second lower than the average grade obtained by this sample as a whole.

In conclusion and as a whole then, the class profile was that of an average student with a lower intermediate level of English who is neither very anxious, nor very relaxed. She or he has a high general aptitude for languages with a higher one for language analysis - the ability to reason with logic in terms of the foreign language. The more worried they were about their FL speaking skills the higher their level of English was according to the correlation figures.

The bilingual CLIL students had a similar a profile but differed on a few main points. They obtained amongst the highest marks in the group for level of English, got a total high aptitude score for languages on the PLAB and especially on sound discrimination and sounds' association with their written symbols, got higher than the average figure for the class for motivation to learn English, and were amongst the most relaxed students in the sample.

Finally, it may be said that the bilingual CLIL students' academic content marks were significantly different and better than the rest of the class. 


\section{Acknowledgements}

This work was financed by the Science and Innovation Ministry of Spain and with co-financing from the European Commission's FEDER (European Fund for Regional Development) as part of the $\mathrm{r}+\mathrm{d}$ project: "BILINGUNI: Total Bilingualism - Follow-up in the university area of students originating from the bilingual CLIL system of secondary education", number FFI200803919/FILO.

\section{References}

[1] Airey, J. (2009). 'Estimating undergraduate bilingual scientific literacy in Sweden'. International CLIL Research Journal, 1(1): article 2. http://www.icrj.eu/12-742 (8 May 2011).

[2] Andalusia Education Council (2005). Plan de Fomento de Plurilingüismo: Una política lingüística para la sociedad andaluza (Plan for Encouragement of Plural-lingualism: A linguistic policy for Andalusia). Law published in the BOJA Official Bulletin of the Junta of Andalusia (BOJA Boletín Oficial de la Junta de Andalucía). Published 22 March, 2005.

[3] Andrew, C.M., Lapkin, S., and Swain, M. (1980). Report on the 1979 evaluation of the French immersion program at Allenby and Glenview public schools in Toronto, grades 5, 6 and 7. Ontario Institute for Studies in Education, Toronto.

[4] British Council. (2007). 'Bilingual Project'. http://www.britishcouncil.org/es/spain-educationbilingual-proyect.htm (20 May 2007).

[5] Council of Europe (2003). Common European Framework for Languages: Learning, teaching and evaluation. http://www.coe.int (2 January 2007).

[6] Coyle, D., Hood, P., and Marsh, D. (2010). CLIL Content and Language Integrated Learning. Cambridge: Cambridge University Press.

[7] Cummins, J., and Swain, M. (1986). Bilingualism in Education: Aspects of theory, research and practice. London: Longman.

[8] Donaldson, M. (1978). Children's Minds. London: Fontana Paperbacks, Collins Publishing Group.

[9] Ellis, R. (1986). Understanding Second Language Acquisition. Oxford: Oxford University Press.
[10] Gardner, R.C. (1985). Social Psychology and Second-Language Learning: The Role of Attitudes and Motivation. London, England: Edward Arnold.

[11] Genesee, F. (1979). 'Scholastic effects of French immersion: An overview after ten years'. Interchange, 9, 20-29.

[12] Hamer, J.F., and Blanc, M.H.A. (1989). Bilinguality and Bilingualism. Cambridge: Cambridge University Press.

[13] Hewitt, E. (2006). 'Parental Influence and language learning in elementary school: An empirical study.’ Intesol Journal, 3(1).

[14] Horwitz, E.K.; Horwitz., M.B., and Cope, J.A. (1986). 'Foreign language classroom anxiety'. The Modern Language Journal, 70(2), 125-132.

[15] Martín, O. (2008). 'La enseñanza bilingüe se hace hueco en España' ('Bilingual education makes headway in Spain'). http://www.aprendemas.com (7 April 2008).

[16] MEPSYD, (2007). Los Modelos Lingüísticos. Documento E1. (Linguistic Models. Document E1). Report.

http://www.mepsyd.es/mecd/estadisticas/educativas /cee/2007A/E1.pdf (7 May 2007).

[17] MEPSYD, (2007). Documento E2 sobre lenguas extranjeras de Régimen General de lenguas (Document E2 on foreign languages of the General Regime on languages). Report.

http://www.mepsyd.es/mecd/estadisticas/educativas /cee/2007A/E2.pdf (10 May 2007).

[18] Oficina de Estadística del MEC. Datos básicos de la Educación en España en el curso 2006-2007 (Basic data on education in Spain for the academic year 2006-2007). Report.

http://www.mec.es/mecd/estadisticas/educativas/dc ce/DATOS_Y_CIFRAS_WEB.pdf. (19 May 2007).

[19] Oxford University Press and University of Cambridge Local Examinations Syndicate (2001). Quick Placement Test User Manual (QPT). Oxford: Oxford University Press.

[20] Plimsleur, P., (2010). Plimsleur Language Aptitude Battery. Rockville, MD: Second Language Testing Foundation, Inc.

[21] Richards, J., Platt, J., and Weber, H., (1985). Longman Dictionary of Applied Linguistics. Essex: Longman Group Ltd. 
[22] SPSS. (2001). The Statistical Package for Social Sciences. Chicago, Illinois: SPSS.

[23] Swain, M., and Bruck, M., (Eds.) (1976). 'Immersion education for the majority child'. Canadian Modern Language Review, 32, (all of vol 5).

[24] Tucker, G. R., (1977). 'The linguistic perspective'. In Bilingual Education: Current Perspectives: Linguistics, Vol. 2 (pp. 1-40). Arlington, Virginia: Center for Applied Linguistics. 